\title{
Radiocarbon chronology of Neolithic in the Lower Don and North-eastern Azov Sea
}

\author{
Andrey Tsybrij 1, Viktor Tsybrij 1, Ekaterina Dolbunova 2, Andrey Mazurkevich 2, \\ Marianna Kulkova 3 and Ganna Zaitseva 4 \\ 1 The Don Archaeological Society, Rostov-on-Don, RU \\ tsybriya@mail.ru \\ 2The State Hermitage Museum, Sankt-Peterburg, RU \\ a-mazurkevich@mail.ru; katjer@mail.ru \\ 3Herzen State Pedagogical University, Sankt-Peterburg, RU \\ kulkova@mail.ru \\ 4Institute for the History of Material Culture RAS, Sankt-Peterburg, RU \\ zai-ganna@mail.ru
}

\begin{abstract}
So far, four different cultural-chronological groups of sites have been identified in the North-eastern Azov Sea and Lower Don River areas, including sites of the Rakushechny Yar culture, Matveev Kurgan culture, Donets culture, and sites of the Caspian-Ciscaucasian region. An analysis of all known dates, as well as the contexts and stratigraphies of the sites, allowed us to form a new perspective of the chronology of southern Russia, to revise the chronology of this region, and change the concept of unreliability of dates for this area.
\end{abstract}

KEY WORDS - Neolithic; chronology; earliest pottery; Lower Don; North-Eastern Azov Sea

\section{Radiokarbonska kronologija neolitika na območju spodnjega toka reke Don in v severovzhodnem delu Azovskega morja}

IZVLEČEK - Na območjih severovzhodnega dela Azovskega morja in spodnjega toka reke Don so bile do danes prepoznane štiri različne kulturno-kronološke skupine najdišč, ki vključujejo najdišča kulture Rakushechny Yar, kulture Matveev Kurgan, kulture Donets in druga najdišča v kaspijsko - ciskavkaški regiji. $Z$ analizo vseh znanih radiokarbonskih datumov, njihovih kontekstov in stratigrafij na najdiščih, smo lahko oblikovali nove poglede na kronologijo južne Rusije, revidirali staro kronologijo in spremenili odnos do datumov, ki so veljali za nezanesljive.

KLJUČNE BESEDE - neolitik; kronologija; najzgodnejša lončenina; spodnji tok reke Don; severovzhodni del Azovskega morja

\section{Introduction}

The Neolithic period of the North-eastern and Eastern Azov Sea areas has been investigated for more than 50 years, and over 100 radiocarbon dates are available (Tab. 1). Four different cultural-chronological groups of sites are now distinguished here. They include sites of the Rakushechny Yar culture (the Lower Don River), Matveev Kurgan culture (Mius River), sites of Donets culture (Low Siversky Donets River) and of the Caspian-Ciscaucasian cultural group (Tsybrij 2008; Belanovskaya 1995; Krizhevskaya 1991; for the areas of these cultures' distribution, see Gorelik et al. 2016). Each of these cultures is repre- 
sented by several sites (see Tsybrij 2008). In the majority of cases, the Neolithic period in this region is marked by the appearance of pottery, an intensification of sedentism, the appearance of 'wattle and daub' architecture (at some sites), specific anthropomorphic and zoomorphic plastics, and new features in the stone industry. The previous determination of domesticated animals at the Matveev kurgan I site dated to the end of the $7^{\text {th }}$ millennium BC were reexamined (Krizhevskaya 1991; Gorelik et al. 2016. 149); evidence of domesticated animals at the Rakushechny Yar site are under discussion (Tsybrij et al. 2017).

This article will give an overview of chronological frameworks of these cultures, with a particular focus on Rakushechny Yar (Fig. 1). An analysis of all the known dates, as well as a context and stratigraphy, allowed a new view and revision of the chronology of south-western Russia, as well as changes of the concept of unreliability of dates for this region (cf. Motuzaite Matuzeviciute et al. 2015.657-658) based on the Rakushechny Yar case study.

\section{Rakushechny Yar: in search of old excavations and new studies}

Rakushechny Yar culture was distinguished by Tatyana D. Belanovskaya on the basis of materials from the Rakushechny Yar site, which yielded a very particular set of finds related to a complex subsistence system (Belanovskaya 1983; 1995). Only few sites are attributed to this culture: an early phase ( $7^{\text {th }}-6^{\text {th }}$ millenium BC), including Rakushechny Yar (layers 23-11) and Razdorskoe I (layer 1). The later Neolithic phases ( $5^{\text {th }}$ millenium $B C$ ) include Rakushechny Yar (layer 5) and Samsonovskoe (layer 6) (Tsybrij 2008.51-52).

Rakushechny Yar is located in the Rostovsky region, on the island of Porechny near the village of Razdorskaya. Porechny is of nonhomogeneous geomorphological structure (Velichko et al. 2011). The north-western part is located in a high flood-plain area, and the south-western part on a low flood-plain. These two flood plains can be clearly seen from the opposite bank of the Don River. It might be suggested that the outer part of the right river bank where the site was located became separated when a new riverbed was forming, and thus the island appeared (Velichko et al. 2011). Much of the site has been destroyed and is still being destroyed. This can be clearly seen by comparing images of the island on 19th century maps and photos of the 1960s, and modern investigations.

The site was discovered in 1956 by Leonid T. Agarkov, a teacher at Razdorskaya village. It was excavated in 1959-1966, 1968, 1971, 1976-1977, and 1979 by Leningrad University expeditions headed by Belanovskaya; the various excavations were made that acquired different names (Fig. 2) $\mathbf{1}$. Collections obtained during excavations by Belanovskaya in the 1960s-1970s (Belanovskaya 1995) and later (Aleksandrovsky et al. 2009; Tsybryi et al. 2014) helped creating a typology of these materials (Mazurkevich, Dolbunova 2015), and an analysis of the site's stratigraphy and chronology. In 2008-2013 and 20162017, new excavations were conducted (Tsybrij et al. 2014), and the stratigraphy that was revealed appeared to be very similar to that described by Belanovskaya of excavations I-III and a trench made by Dmitry Y. Telegin in 1975, which was located, according to archive data, between trenches IV-V made by Belanovskaya (Figs. 2-4).

The geological deposits on the site are up to $6 \mathrm{~m}$ deep and the cultural layers up to $5 \mathrm{~m}$. According to Bela-

1 Usually only the materials from excavation I are presented in the publications. 
novskaya, the cultural layers can be traced to a distance of $240 \mathrm{~m}$ to the south-east. The borders of the site inside the island are not clearly defined. The layers are not distributed uniformly and their number varies in different parts of the island. Only the upper layers (1-5) are deposited uniformly, whereas the layers below are isolated and vary in depth and area and are often separated by sterile layers of sand. This is what complicates the correlation of layers of excavations in different parts of the island. From the very outset, Belanovskaya noted that only the layers of excavations I-III can be correlated based on stratigraphic observation. This is why each part that was excavated has its own numbering system, which can be correlated only on the basis of ${ }^{14} \mathrm{C}$ dates from precise layers (see Fig. 3). Future excavations and the connection of all of the excavated areas will allow us to correlate stratigraphic units of different parts.

The surface excavated in the 1960s-1970s amounted to $1000 \mathrm{~m}^{2}$ (Belanovskaya 1995.9-12). The main trench (trench I) was in the northern part of the island (Fig. 2). Six horizons were distinguished here based on a very precise lithology, included cultural layers, often separated by sterile interlayers. The upper cultural layers of the Eneolithic and Later Neolithic period (layers 4 and 5) include thick layers filled by Viviparus dilluvianus shells, which were cemented together and protected the underlying lay- ers from being destroyed (Belanovskaya 1995). The low horizon (correlated with horizon VI of Telegin; Fig. 3a) included several thin lithological layers (2$25 \mathrm{~cm}$ ) (Fig. 3f). Cultural layers 23-12 were separated by sterile sand interlayers, and layers $12-10$ by sandy clay $5-10 \mathrm{~cm}$ thick. No remains of structures were found in layers $23-18$, besides shell piles with a great amount of fish and animal bones, charcoal and artefacts inside and nearby. Post pits, fire-places on clay platform-floors, shell piles, daub fragments from the walls/roofs of dwellings were found in layers above. The particularities of microstratigraphy and the spatial distribution of finds allows us to suppose that the inhabitants of this ancient settlement had to leave this place periodically (at least the part excavated), probably due to seasonal flooding of the paleoriver, but then they returned (Belanovskaya 1995.13). A particular material culture was revealed in the Neolithic layers, with flat-bottom pottery, predominantly undecorated, flint borers, slate chisels, and numerous bone points and antler hoes (Figs. 5-8).

Cultural layers 6-23 were attributed to the Neolithic (Belanovskaya 1995). Telegin identified six lithological horizons here, attributing horizons 4-6 to Early Neolithic layers (Telegin 1981) (Fig. 3a). This is a very important point, because the numbering of layers, indicated by Telegin, does not correspond to the now widely used layer numbering system pro-

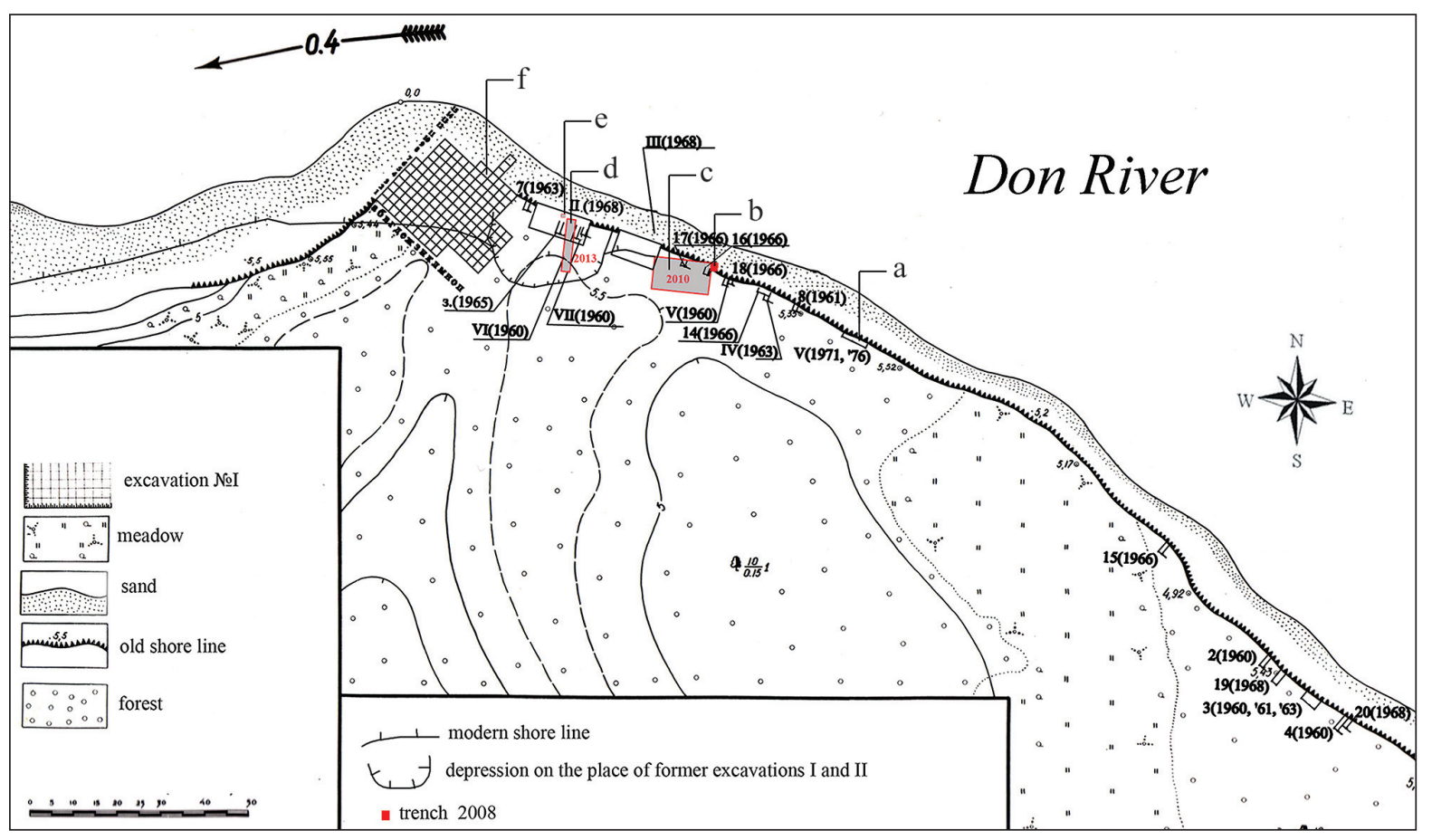

Fig. 2. Rakushechny Yar site. Plan of excavations in the 1960-1970s, and new excavations in 20082016 (for a-f see Fig. 3). 

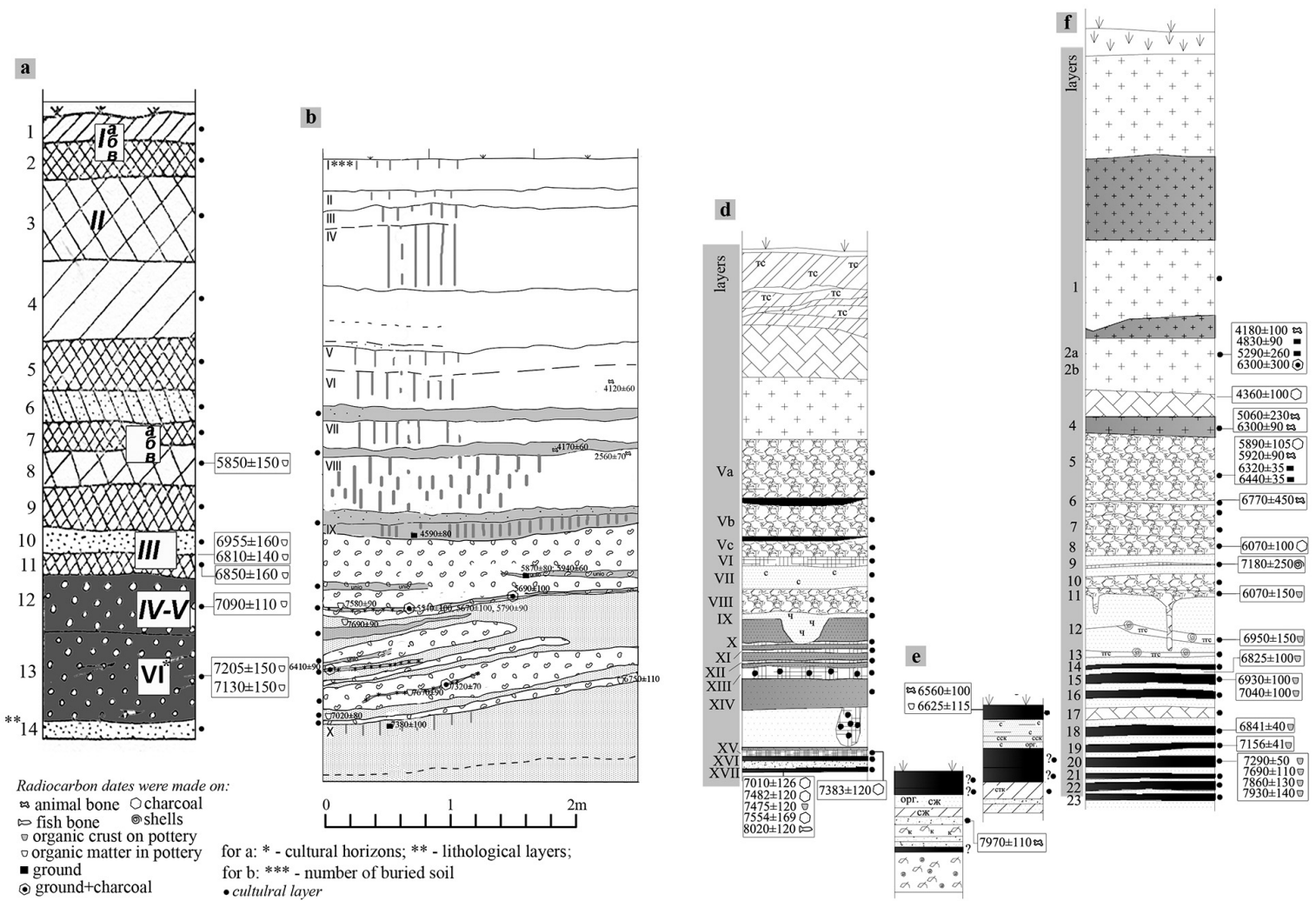

Fig. 3. Rakushechny Yar. a stratigraphy of Telegin's excavation (from Telegin 1981); b stratigraphy of excavation of 2008 (modified from Aleksandrovky et al. 2009); d stratigraphy of trench 2013; e sondages \#1, \#2 and new excavations of 2016-2017; f excavation I by Belanovskaya in 1966 (modified from Belanovskaya 1995; the lower layers 16-23 were drawn according to description). See the description of the lithological layers in the text.

posed by Belanovskaya, so dates made on materials with the firmer index system cannot be correlated with other dates without a special analysis of materials and discussion (cf. Kotova 2002; Manko 2006 etc.).

In order to refine the stratigraphy of the site and its chronology, which remained a subject of discussion, a stratigraphic trench was made in 2013, and further excavations carried out during 2016-2017, which allowed us to precisely place the previous excavations by Belanovskaya, to correlate the stratigraphy of different parts of the settlement and obtain new materials for radiocarbon dating.

\section{Chronology of the Rakushechny Yar site}

The chronology of the settlement can be reconstructed based on radiocarbon dates made on different materials - charcoal, bone, soil and organic crust - from trench I of the 1960s (Belanovskaya et al. 2003; Belanovskaya, Timofeev 2003), from the trench dug in 2008 (that might be located near excavation 16 made by Belanovskaya) and enlarged in 2010, and from the trench dug in 2013 at the location of the II by Belanovskaya (Tsybrij et al. 2014) (Fig. 3). The stratigraphy of different excavations was correlated in order to refine the chronology of the site, new samples were selected, and artefacts, including dated samples, were spatially analysed.

Most of the radiocarbon dates of the organic materials from excavation I correlate rather well with each other (Tab. 1; Fig. 9). They show the dynamics of occupation of the site. The dates of materials from layer 20 might reflect different periods of occupation of the site. Only the dates of shells, and some dates of mixed samples of charcoal and soil could have been influenced by some postdepositional processes, and these do not reflect the real date of the layers' formation. Comparing the dates of fish bones and other materials from one layer, it is evident that the dates of the former appear to be older (Tab. 1.29). However, it must be noted that there is not enough data and materials to discuss the possibility and extent of the reservoir effect on this site.

Another set of dates was obtained from materials from the lower layers of the trench dug at excavation II in 2013, from the trench of 2008, and pottery 
from excavations by Telegin in 1975 (Telegin 1981), which allowed us to establish the radiocarbon chronology of different parts of the site. Charcoal from a shell pile (layer XVII, trench of 2013) was dated to $7554 \pm 169$ $\mathrm{BP}(\mathrm{Ua}-48460)(\delta 13 \mathrm{C}-22.6)$ and $7010 \pm 126 \mathrm{BP}(\mathrm{Ua}-48461)(\delta 13 \mathrm{C}$ -23.0) (6590-6230 and 60005760 cal BC). It is clear in Figure 3 that a direct correlation of lithological layers in the lower part of the sediments of this site is impossible due to the different number and features of lithological and cultural layers. A direct corre-

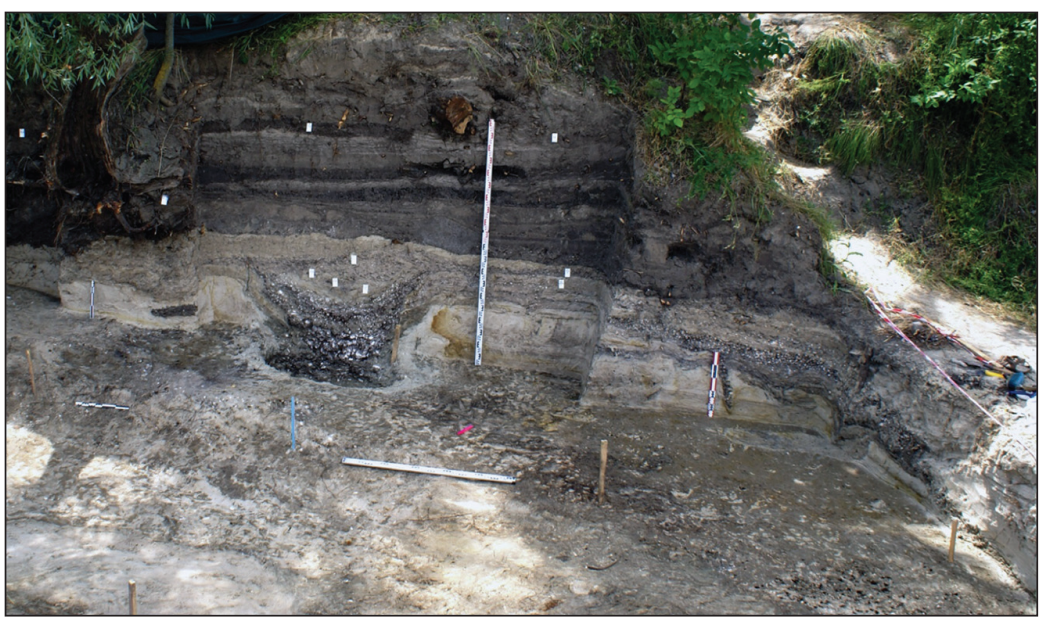

Fig. 4. Rakushechny Yar. Stratigraphy of the excavation at the site of trenches II-III by T. D. Belanovskaya (excavation 'e'. 2016). lation of layers based on their height values is also impossible, as the layers lie in an oblique position, at different heights in different places (Fig. 4). The radiocarbon date of an elk bone of $7970 \pm 110 \mathrm{BP}$ (SPb-729) (7179-6596 cal BC) (Fig. 3e) allows its synchronisation with layers 21-23 (excavation No. I of Belanovskaya). Radiocarbon dates and stratigra- phic observations on the area of excavations I-III allowed us to date the earliest stages of occupation to 7186-6472 cal BC.

Another group of dates of various materials (bones, pottery, soil with charcoal and soil) from the trench of 2008 presents a completely different picture (Fig.

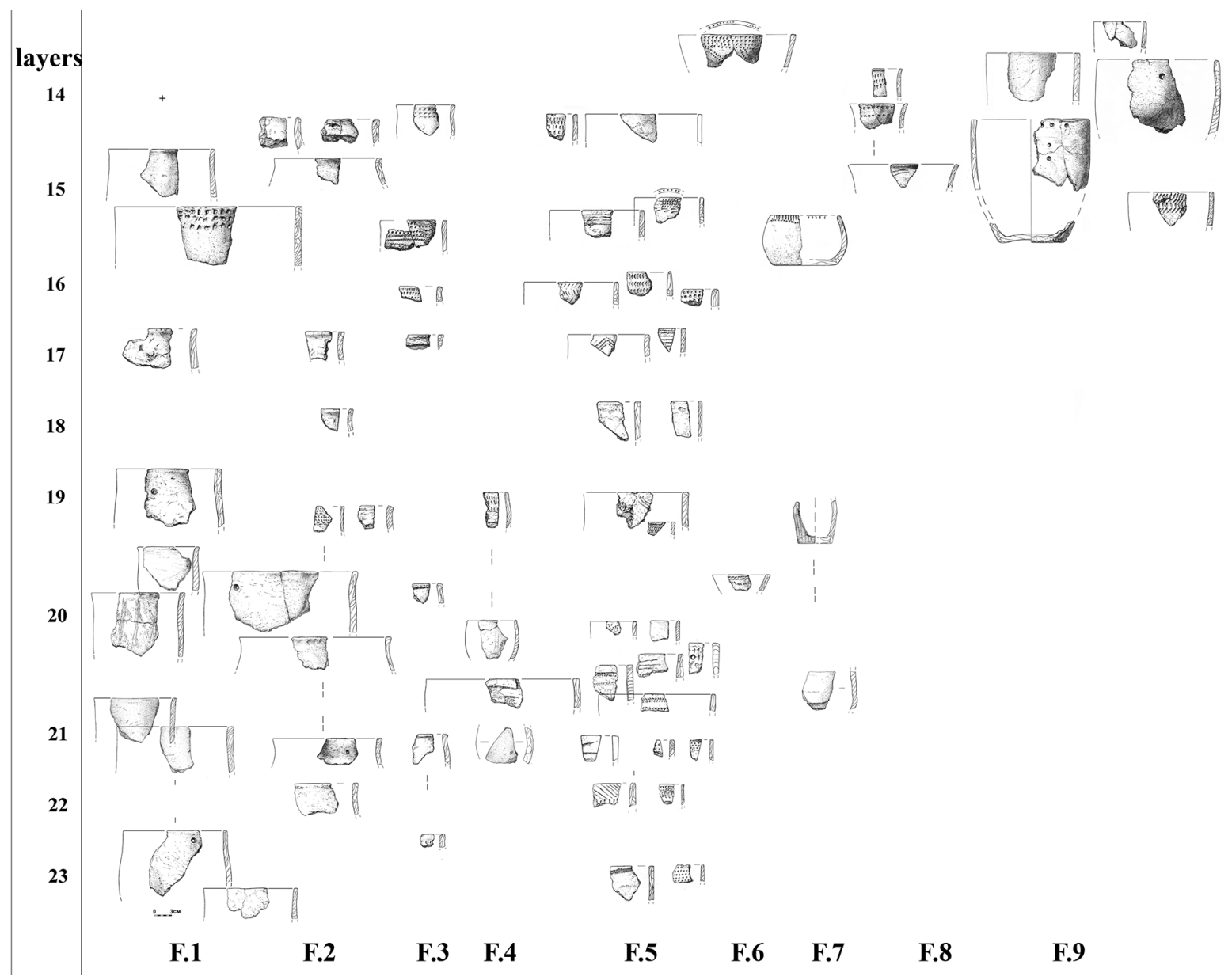

Fig. 5. Rakushechny Yar. Vessel forms in layers 23-14 (after Mazurkevich, Dolbunova 2015). 


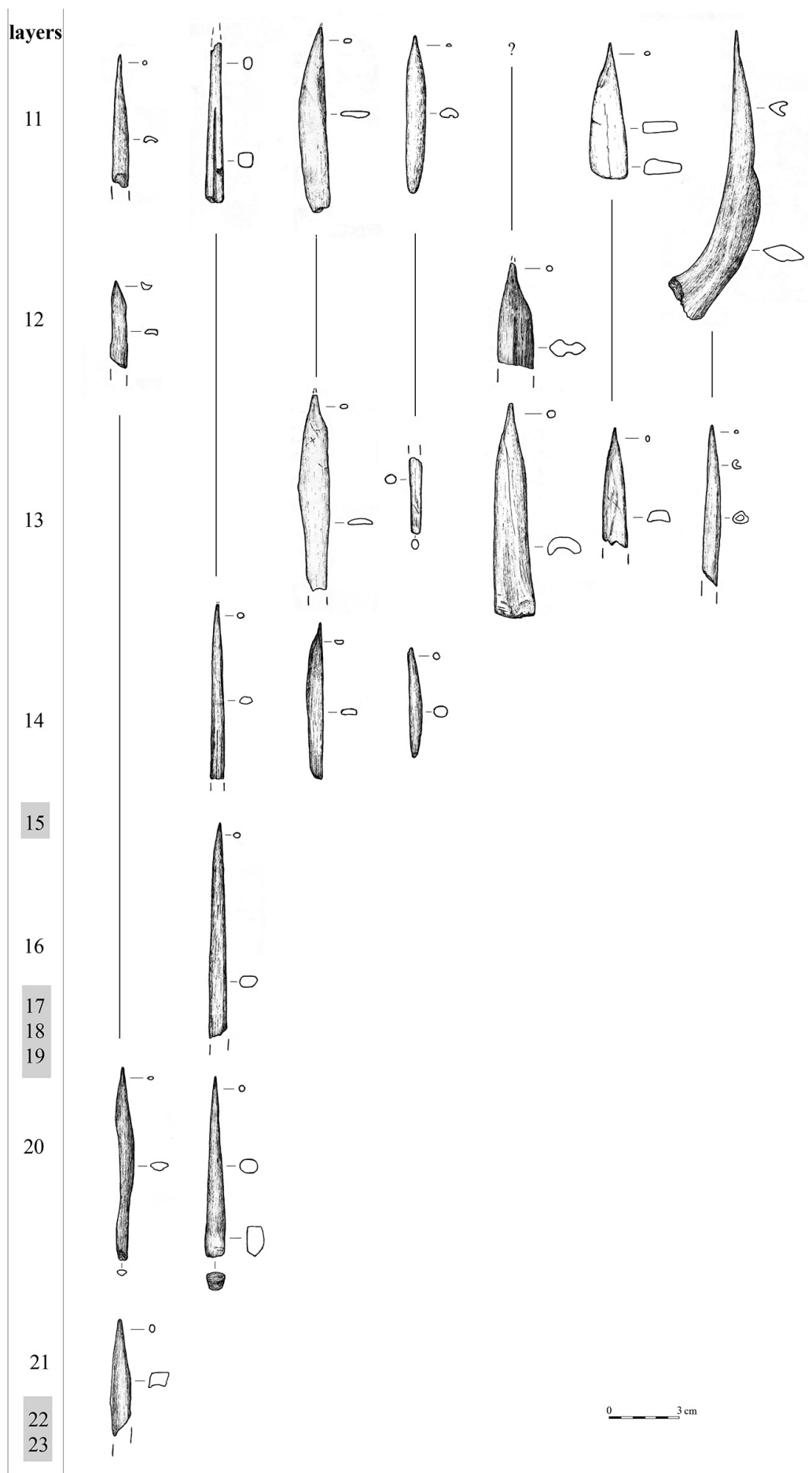

Fig. 6. Rakushechny Yar. Bone points in layers 23-11. dates of soils and charcoal from cultural layers. The buried soil No. $\mathrm{X}$ from the trench of 2008 , lying on the bottom of cultural layers, was dated to $7380 \pm 100 \mathrm{BP}(\mathrm{Ki}-$ 15181) (6431-6061 cal BC), i.e. this part was inhabited approx. 600 years later than the low layers from the place where excavations I-III by Belanovskaya were made. According to Alexander L. Aleksandrovsky, the process of soil formation started here later, as it was located lower than excavation I and occurred over a period of 100-200 years. Only when the area of excavation I was inhabited did the soil start to form here. We might synchronise the beginning of occupation and the formation of a cultural layer, which occurred between the period of layers 20 and 19 (excavation I - Fig. 3f) and during the period of layer XVI (location of excavations II-III - Fig. 3d). Further short periods of occupation, marked by thin sandy layers with Unio shells under the buried soil (IX Fig. 3b) can be synchronised with layers 11-9 (excavation I - Fig. 3f).

The last group of dates were made on materials from the trench of Telegin dug in 1975 (Fig. 3a), located in the same place as excavation $V$ by Belanovskaya, far to the south-east of the main area of excavation (trenches I-II). The stratigraphy of this trench is similar to that of the trench dug in 2008 (Fig. 3b). The dates were made on organic matter in pottery, and they show that this place might have been first inha-

$3 \mathrm{~b})$. The trench is located to the south-east of the excavation I-III (Fig. 2). The dates of the soil and soil with charcoal are in chronological correspondence. In most cases, the dates of pottery and bones from dated charcoal interlayers are older, and slightly younger in only few cases. This needs to be discussed further and can be explained only after new excavations on this part. This is why we will base our chronological reconstructions for this part on the bited at approximately the same time as the low layer of the trench dug in 2008. The typology of the dated vessels also supports this assumption.

Various layers traced in different parts of the island (Figs. 2; 3.a-f) can be correlated precisely on the basis of radiocarbon dates, as artefacts attributed to the Early Neolithic comprise a rather homogenous complex that preserved a range of features that seem 
to survive through centuries. Nevertheless, more dating of different materials and the connection of different excavation areas are needed in order to refine the chronology of this part of the site, and the correlation of the various layers.

The differences in radiocarbon dates, number and character of cultural layers support suggestion of Belanovskaya's that the cultural layers revealed on the shore line and in different trenches cannot be correlated directly, and such 'diversity' shows that this part of the modern island was inhabited repeatedly during different periods. Taking into account that different parts of the site were excavated, their correlation is problematic, as their length and thickness varies, especially in lower layers. This is a departure point for discussing the validity of the dates derived

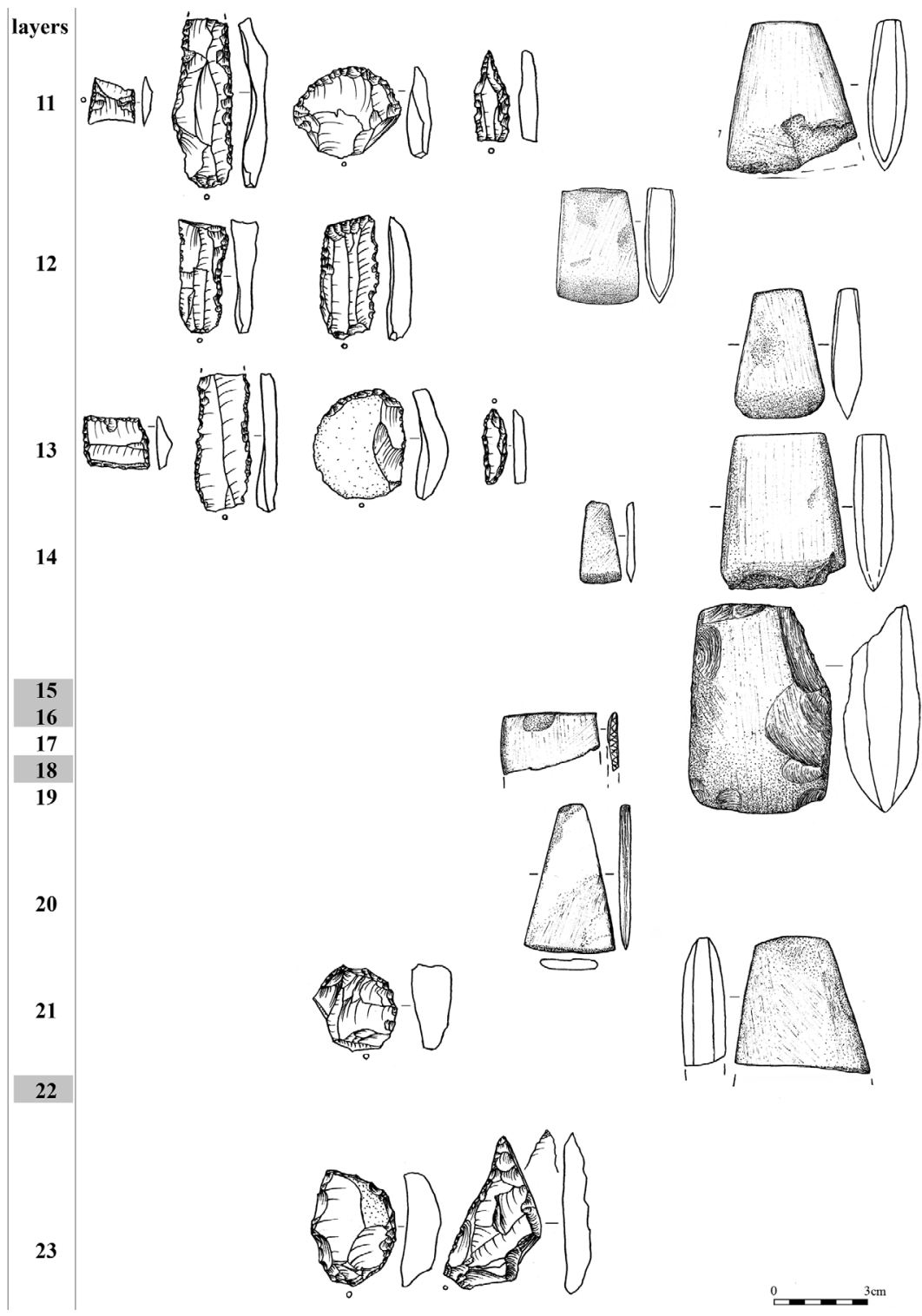

Fig. 7. Rakushechny Yar. Flint and slate tools in layers 23-11 (from Lozovsky 2014; drawings done by V. M. Lozovsky and E. Dolbunova). from material from different layers of the site $(\mathrm{MO}$ tuzaite Matuzeviciute et al. 2015.662; for example, dates presented in Motuzaite Matuzeviciute 2012. Tab. 1 for Rakushechny Yar are attributed to layers of different areas of the site and cannot be presented together). The main problem is that the dates were obtained from material from different excavated areas located in different parts of the island that cannot be correlated with each other, and not that some processes have influenced the dates. Moreover, it is important to consider the particularities of the layers' formation and seasonal occupation of this site over a long period. For example, given their thickness, layers 5 and 4 could have been accumulated during a long period.

The dates also point to another important problem: the time of accumulation of cultural layers and deposition of materials. The lower cultural layers of excavations I-III are filled with piles of Unio shells, fish scales and bones, animal bones and artefacts covered by thin and sterile sandy interlayers. The cultural layers could have been buried under thin sandy layers either after a single seasonal event or accumulated over longer periods. Different parts of the shore zone might have been inhabited, which can be archaeologically traced in radiocarbon dates. It is important to note that objects are recorded mostly in situ in the cultural layers (Fig. 8); the distribution of finds indicates only a slight disturbance of the cultural layers.

Razdorskaya II is located on the right bank of the Don River, six kilometres downstream from Rakushechny Yar (Tsybrij 2008). It is a multilayered site, with predominantly Viviparus shell accumulation, and is rich in fish bones, charcoal, artefacts, and faunal remains. Fishing activity occupied an important place in the economy of Razdorskaya II, as it did at Rakushechny Yar. This is evident from the particu- 
larities of the cultural layer (Fig. 10), with stratified shell piles and an inventory which includes a large number of sinkers, axes and bone spears. No pottery was found here, although small ceramic figurines were found. Due to the particular material culture of this site, it was attributed to a specific cultural type. Radiocarbon dates were made on materials from the middle and low cultural layers (Aleksandrovsky et al. 2009) (Fig. 10). The early stages of this site are attributed to the earliest aceramic Neolithic phase at the end of the $8^{\text {th }}$ - beginning of the $7^{\text {th }}$ millennium BC. That this site continued to be occupied is evidenced by ${ }^{14} \mathrm{C}$ dates within the range of the $7^{\text {th }}$ and the beginning of the $6^{\text {th }}$ millennium BC (Tab. 1), which suggest it was contemporaneous with Rakushechny Yar.

\section{Matveev Kurgan culture, Donets culture and sites of the Caspian-Ciscaucasian cultural group}

Matveev Kurgan culture was named after Matveev Kurgan I and II sites, located in North-Eastern Azov Sea area, which were excavated in the 1970-1980s by Lija Y. Krizhevskaya (Krizhevskaya 1991). Some similarities can be traced with the Lower Don River Neolithic sites. It can be attributed to the very beginning of Neolithic era and dated to the middle - second half of the $7^{\text {th }}$ millennium BC, although more ${ }^{14} \mathrm{C}$ dates would be needed to refine the chronological position of this culture. Later stages were not found here.

Donets culture was discovered in 1952 by Aleksandr Y. Brusov and was later re-analyzed and re-interpreted in the 1960s to 1990s (Brusov 1952; Telegin 1968; Danilenko 1969; Gorelik 1984; 1997). One of the typical features of this culture is the survival of archaic traits in the stone industry for a long period and a small amount of pottery. Complexes attributed to the early phases of Donets culture can be synchronised with Matveev Kurgan culture and dated to the end of the $7^{\text {th }}$ millennium BC. Later phases can be dated to the second half of the $6^{\text {th }}$ and the first half of the $5^{\text {th }}$ millennium BC, and synchronised with layer 5 at Rakushechny Yar site (the chronology is based on typological correlation of materials).

The Caspian-Ciscaucasian cultural group includes material from Kremennaya II and III, Rassypnaya VI and Lagutinskaya, as well as finds from the basins of the steppe rivers of the Rostov oblast' (Tsybrij 2008.60). The stone items are similar to material from the Northern Ciscaucasian, North-Western and Northern Caspian area. The pottery is not abundant. Kremen-

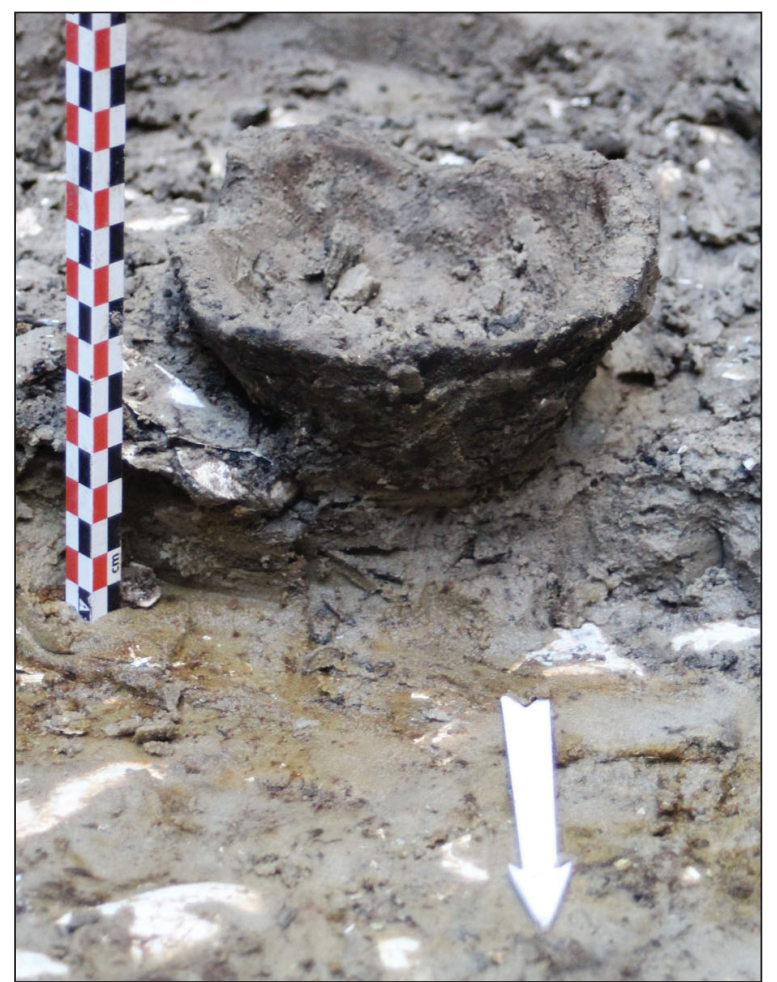

Fig. 8. Rakushechny Yar. Low part of a flat bottomvessel standing on the Unio shell layer No. XVI (excavation 'd' 2013).

naya II and Rassypnaya VI are attributed to early stages of the Neolithic period, and Kremennaya III to a later stage.

Kremennaya II is located in the Gnilaya River basin, near the village of Zolotovsky (Milutinsky district, Rostovskaya oblast'). The stone industry of the site is characterised by a blade and microlith inventory, including different types of geometrical microliths with secondary treatment: segments, parallelograms, trapezes and backed trapezes. The pottery is not abundant. More than 50 dug-out hearths were found in the base of cultural layer - 15 of which were dated (Fig. 11) - which reveal different stages of occupation of this site during the Neolithic from the $6^{\text {th }}$ to the $5^{\text {th }}$ millennium $\mathrm{BC}$.

Kremennaya III is located near Kremennaya II, at a low hypsometric level. The pottery is not abundant, the flint tools are larger and are similar to tools at Kremennaya II. New tools appeared: polished flint heavy duty tools and arrowheads. A fragment of a copper plate was found in a cultural layer (Tsybryi 2008). Four radiocarbon dates were made on animal bones, also revealing different periods of occupation at this site: the end of the $7^{\text {th }}$ to the first half of the $6^{\text {th }}$ millennium $\mathrm{BC}$, and during the $5^{\text {th }}$ millennium BC. 


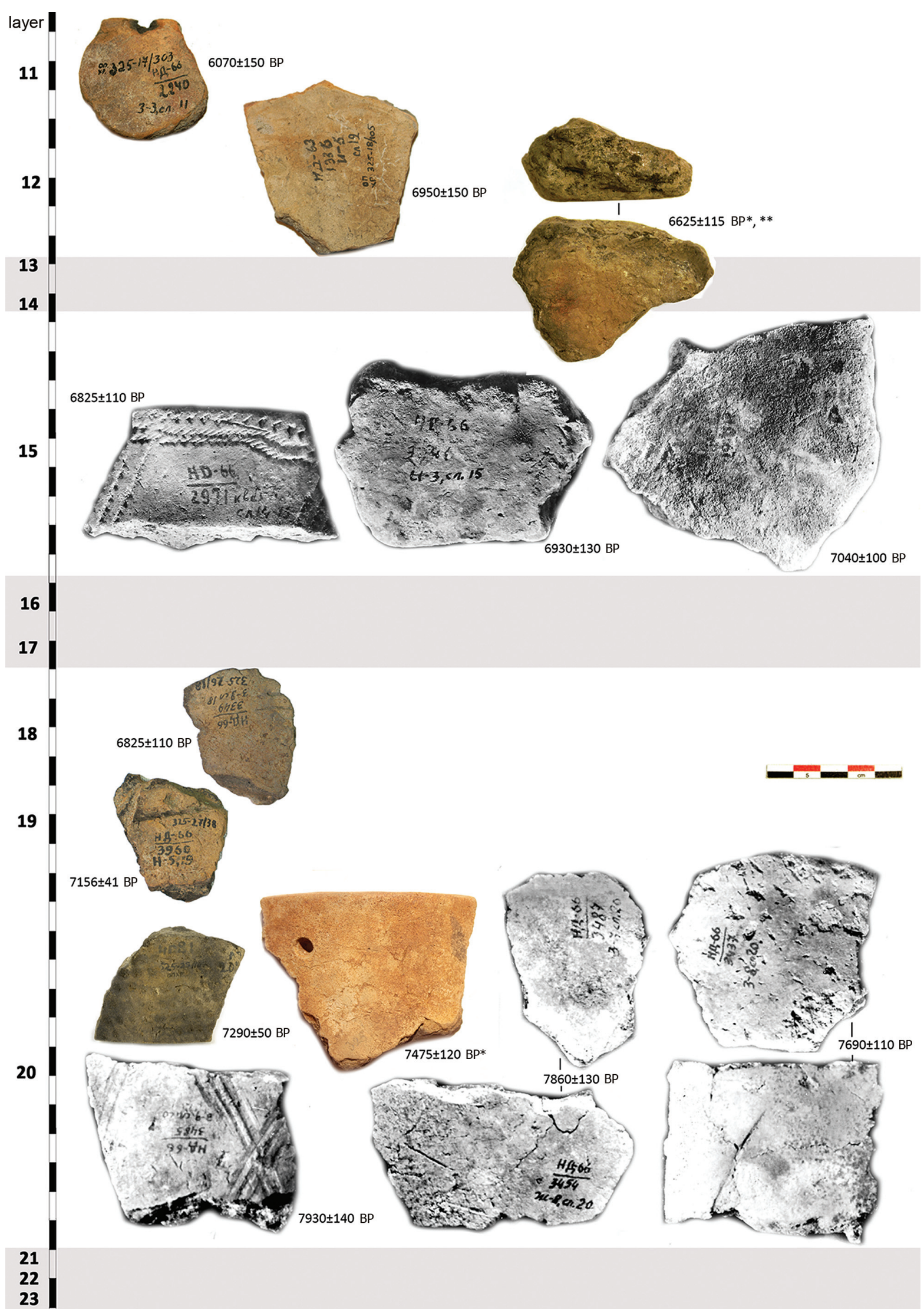

Fig. 9. Fragments of ${ }^{14} \mathrm{C}$ dated pottery (material for dating - organic crust) from excavation I, with an indication of the layers where they were found. * fragments from the excavation of 2013; ** pottery fragment was dated. 

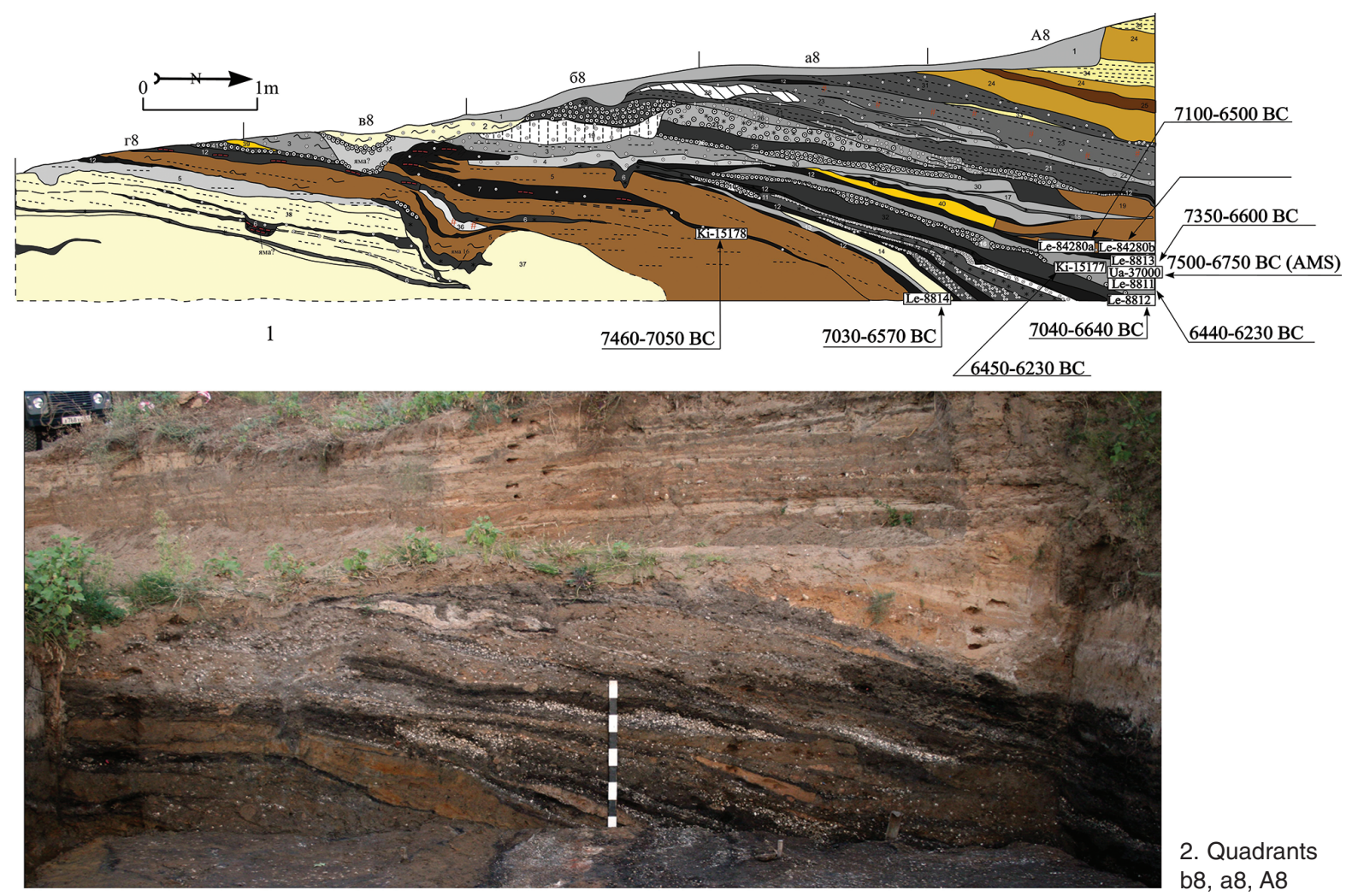

2. Quadrants b8, a8, A8

Fig. 10. Razdorskaya II. Stratigraphy profile, with indication of places where samples for dating were taken.

Rassypnaya VI is located in the Rassypnaya valley (Tsybrij 2003). The flint industry is similar to that at Kremennaya II and III and other sites in the Eastern Azov basin (Rassypnaya 1, Zhukovskaya 2, etc.). Microlithic tools predominate, including segments, parallelograms and trapezes, including backed trapezes. The pottery is not abundant; it was decorated by comb stamp and traced lines organised in simple compositions. Dates were made on five animal bones and one bone from burial 1, found at the bottom of cultural layer of the site (Fig. 12). Given the typology, we can suppose that most material can be dated to the last quarter of the $6^{\text {th }}$ to the first quarter of the $5^{\text {th }}$ millennium BC. Although this site was probably also visited/inhabited during the $7^{\text {th }}$ and second half of the $5^{\text {th }}$ millennium $\mathrm{BC}$.

\section{Conclusion}

The Lower Don River and North-eastern Azov Sea encompass several archaeological cultures, including Rakushechny Yar, Matveev Kurgan, Donets and the Caspian-Ciscaucasian cultural group. The chronological timeframes of these cultures are contemporaneous, which indicates the mosaic cultural character of this area during the period between the $7^{\text {th }}$ and $5^{\text {th }}$ millennium BC. The small number of radiocarbon dates for such a long period prevents us from refin- ing the chronology of the different cultural groups and definite ceramic types within this area.

The Razdorskaya II site located in the Lower Don River basin is supposed to be one of the most ancient sites attributed to the Neolithic era (see discussion of the term 'Neolithic' in Mazurkevich, Dolbunova 2015), having a particular stone industry and complex subsistence strategy, predominantly fishing, but with no pottery. The early stages of this site are attributed to the earliest non-ceramic Neolithic phase, at the end of the $8^{\text {th }}$ and beginning of the $7^{\text {th }}$ millennium $\mathrm{BC}$. This site was inhabited later, during the $7^{\text {th }}$ and beginning of the $6^{\text {th }}$ millennium $\mathrm{BC}$, which suggest its contemporaneity with Rakushechny Yar. New research of the latter site allowed us to revise its stratigraphy, archaeological context and chronology. The differences in radiocarbon dates, number and character of cultural layers which were revealed support Belanovskaya's suggestion that the cultural layers located on the shore line and different trenches cannot be correlated directly. Such 'diversity' shows that this part of the modern island was inhabited repeatedly during different periods.

The Rakushechny Yar culture existed, probably, for approx. 1500 years, during the $7^{\text {th }}$ and $6^{\text {th }}$ millennium BC. It must be noted that the material culture 


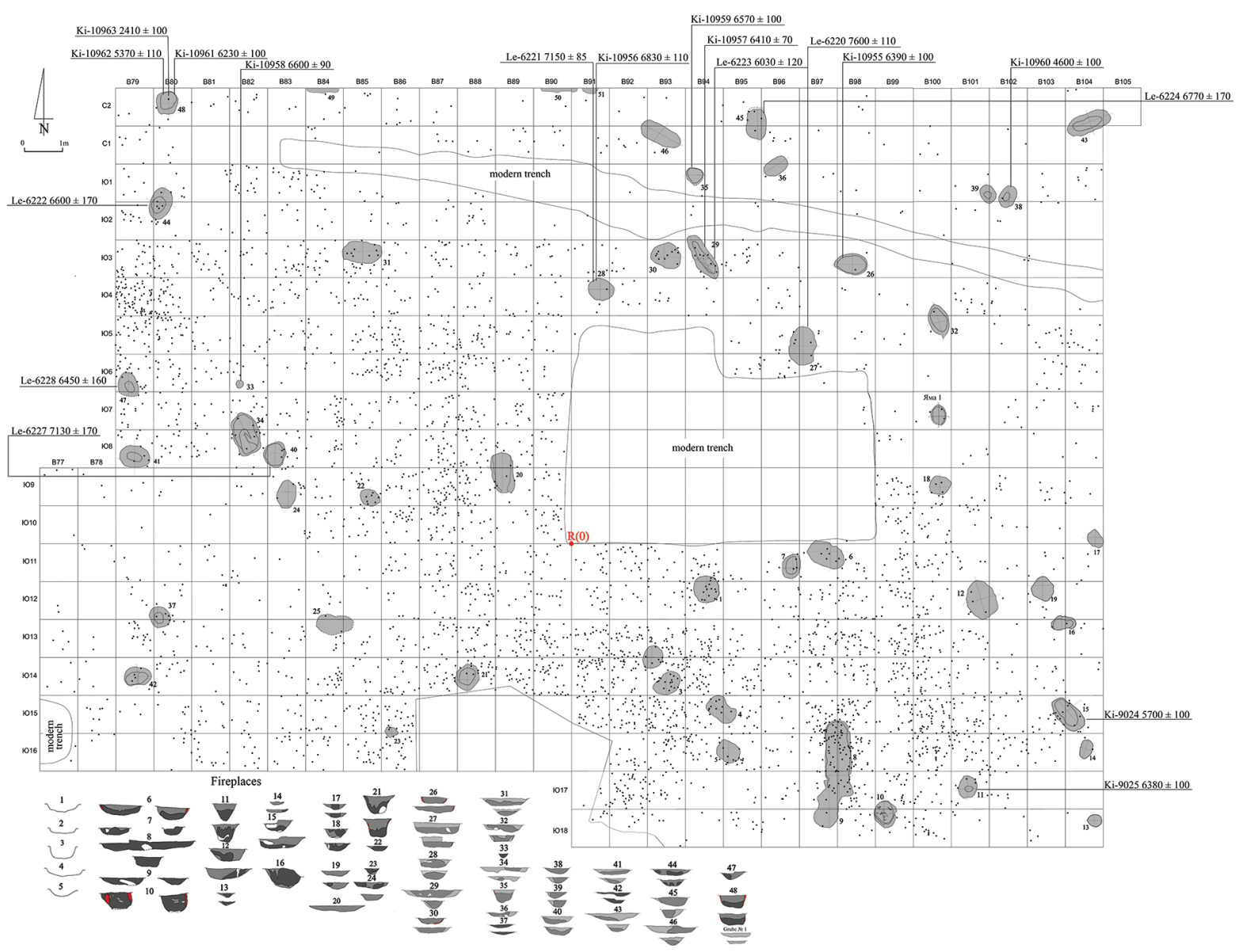

Fig. 11. Kremennaya II. Plan of the excavation 2, with the objects dated.

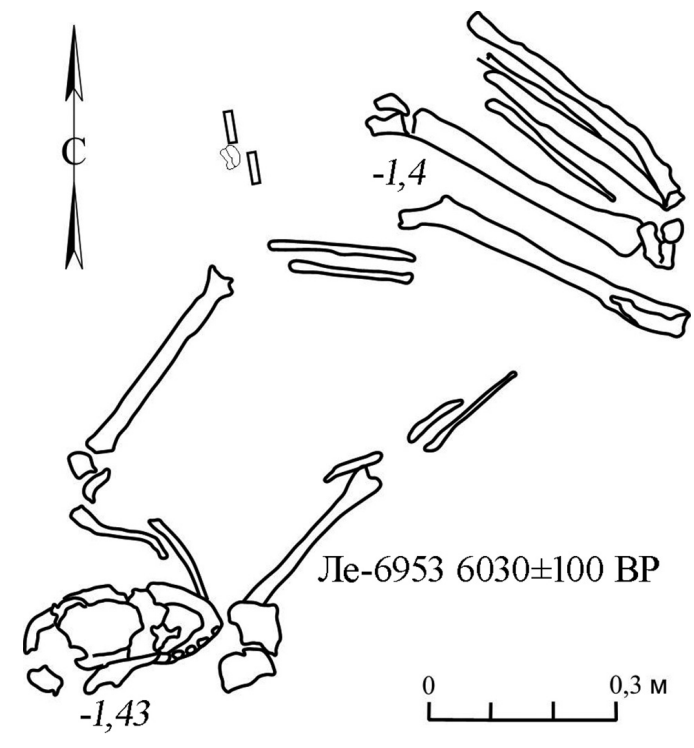

Fig. 12. Rassypnaya VI. Excavation 2, burial 1. was very conservative and retained a number of specific traits through centuries. New dates and the analysis of radiocarbon dates, taking into the account stratigraphy of excavations and spatial analysis of finds, point to the first half of the $7^{\text {th }}$ millennium BC as the period when Rakushechny Yar appeared, with one of the earliest ceramic in Eastern Europe. The excavated area was a seasonal site with a particular set of finds, including different animal and fish bones, hearths, 'wattle and daub' architecture, and an anthropomorphic figurine made on horse pastern. Previous discussions about the estimated dates made for this site arose not because of the validity of dates, but their presentation as they were analysed out of context. Our analysis of archived materials and new excavations allowed us to refine the chronology of this site and change the idea of unreliability of radiocarbon dates for this site. 


\section{References}

Aleksandrovsky A. L., Belanovskaya T. D., Dolukhanov P. M., Kiyashko V. Ya., Kremenetsky K. V., Lavrentiev N. V., Shukurov A. M., Tsybrij A. V., Tsybrij V. V., Kovalyukh N. N., Skripkin V. V. and Zaitseva G. I. 2009. The Lower Don Neolithic. In P. Dolukhanov, G. R. Sarson and A. M. Shukurov (ed.), The East European Plain on the Eve of Agriculture. British Archaeological Reports IS. Archaeopress. Oxford: 89-121.

Belanovskaya T. D. 1983. Rakushechnoyarskaya kul'tura vremeni neolita $i$ eneolita na Nizhnem Donu. Problemy hronologii arheologicheskih pamyatnikov stepnoi zony Severnogo Kavkaza. RGU. Rostov-na-Donu: 10-15. (in Russian)

1995. Iz drevneishego proshlogo Nizhnego Podon'ya: poselenie vremeni neolita $i$ eneolita Rakushechnyi Yar. Izdatel'stvo St. Petersburgskogo universiteta. SanktPeterburg. (in Russian)

Belanovskaya T. D., Timofeev V. I. 2003. Mnogosloinoe poselenie Rakushechnyi Yar (Nizhnee Podon'e) i problemy neolitizacii Vostochnoi Evropy. In Neolit - eneolit Yuga $i$ neolit Severa Vostochnoi Evropy (novye materialy, issledovaniya, problemy neolitizacii regionov). Rossiyskaya Akademiya Nauk. Institut materialnoy kulturi. Sankt-Peterburg: 14-21. (in Russian)

Belanovskaya T. D., Timofeev V. I., Zaiceva G. I., Kovalyuh N. N. and Skripkin V. V. 2003. Novye radiouglerodnye daty neoliticheskih sloev mnogosloinogo poseleniya Rakushechnyi Yar. In A. N. Mazurkevich (ed.), Drevnosti Podvin'ya: istoricheskii aspekt. Gosudarstvennyi Ermitazh. Sankt-Peterburg: 134-139. (in Russian)

Bryusov A. Ya. 1952. Ocherki po istorii plemen Evropeiskoi chasti SSSR v neoliticheskuyu epohu. Moskva. (in Russian)

Danilenko V. N. 1969. Neolit Ukrainy. Naukova dumka. Kiev. (in Russian)

Gorelik A. F. 1984. Mezolit Severo-Vostochnogo Prichernomor'ya (voprosy kul'turno-hronologicheskogo chleneniya). In Materialy kamennogo veka na territorii Ukrainy. Naukova dumka. Kiev: 4-23. (in Russian)

1997. Slozhenie doneckoi kul'tury i nekotorye metodologicheskie problemy "neolitizacii" mezoliticheskih kul'tur. In Drevnosti Podoncov'ya. Lugansk: 32-37. (in Russian)

Gorelik A., Tsybrij A. and Tsybrij V. 2016. 'Neolithisation' in the NE Sea of Azov region: one step forward, two steps back? Documenta Praehistorica 43: 139-160.
Kremeneckii K. V. 1991. Paleoekologiya drevneishih zemledel'cev i skotovodov Russkoi ravniny. Geograficheskiy institut Akademiyi Nauk SSSR. Moskva. (in Russian)

Krizhevskaya L. Ya. 1991. Nachalo neolita v stepyah Severnogo Prichernomor'ya. Institut materialnoy kulturi. Sankt-Peterburg. (in Russian)

Kotova N. S. 2002. Neolitizaciya Ukrainy. Shlyah. Lugansk. (in Russian)

Lozovsky V. M. 2014. Tehnologicheskii aspekt kremnevyh industrii rubezha mezolita - neolita Nizhnego Dona i Verhnei Volgi. Arheologicheskie vesti 20: 69-79. (in Russian)

Manko V. 0. 2006. Neolit Pivdenno-Shidnoi Ukraini. Shlyah. Kiev.

Mazurkevich A., Dolbunova E. 2015. The oldest pottery in hunter-gatherer communities and models of Neolithisation of Eastern Europe. Documenta Praehistorica 42: 13-66.

Motuzaite Matuzeviciute G. 2012. The earliest appearance of domesticated plant species and their origins on the western fringes of the Eurasian Steppe. Documenta Praehistorica 39: 1-21.

Motuzaite-Matuzeviciute G., Lillie M. and Telizhenko S. 2015. AMS radiocarbon dating from the Neolithic of Eastern Ukraine casts doubts on existing chronologies. Radiocarbon 57(4): 657-664.

Timofeev V. I., Doluhanov P. M., Zaiceva G. I. and Shukurov A. M. 2004. Radiouglerodnaya hronologiya neolita Severnoi Evrazii. Teza. Sankt-Peterburg. (in Russian)

Telegin D. Y. 1968. Dnipro-donetska kultura. Do istorii naselenija epohi neolita-rannego metalla Pivdnja Shidnoi Evropy. Naukova dumka. Kiev.

1981. Pro neolichishni pam'yatki Podonnyaya I Stepovo Povolzhya. Arheologiya 36: 3-19. (in Russian)

Tsybrij V. V. 2008. Neolit Nizhnego Dona i Severo-Vostochnogo Priazov'ya. Izdatel'stvo Severo-Kavkazskogo nauchnogo centra vysshei shkoly Yuzhnogo federal'nogo universiteta. Rostov-na-Donu. (in Russian)

Tsybrij A. V. 2003. Neoliticheskie pamyatniki Vostochnogo Priazov'ya. In Neolit - eneolit Yuga i neolit Severa Vostochnoi Evropy (novye materialy, issledovaniya, problemy neolitizacii regionov). Rossiyskaya Akademiya Nauk. Institut materialnoy kulturi. Sankt-Peterburg: 41-55. (in Russian) 
2011. K voprosu o hronologii i periodizacii pamyatnikov mezolita, neolita, eneolita Yuga Russkoi ravniny. Kritika odnogo podhoda. Arheologicheskie zapiski 7: 333-341. (in Russian)

Tsybrij A. V., Dolbunova E. V., Mazurkevich A. N., Tsybrij V. V., Gorelik A. F., Motuzaite-Matuzevichute G. and Sablin M. V. 2014. Novye issledovaniya poseleniya Rakushechnyi Yar v 2008-2013g. Samarskii Nauchnyi Vestnik 3 (8): 203-214. (in Russian)

Tsybrij A. V., Tsybrij V. V., Dolbunova E. V., Mazurkevich A. N., Sablin M. V., Meadows J. and Motuzaite Matuzevi- ciute G. 2017. Novye issledovaniya pamyatnika Rakushechnyi Yar i voprosy neolitizacii yuga Vostochnoi Evropy. In A. P. Derevyanko, A. A. Tishkin (eds.), Vserossiiskii arheologicheskii s'ezd: sbornik nauchnyh trudov. Izdatel'stvo AltGU. Barnaul. (in Russian)

Velichko A. A., Morozov T. D. and Timiryazeva S. N. 2011. Osnovnye komponenty razreza golocena Nizhnego Dona (Rakushechnyi Yar). Arheologicheskie zapiski 7: 15-27. (in Russian) 


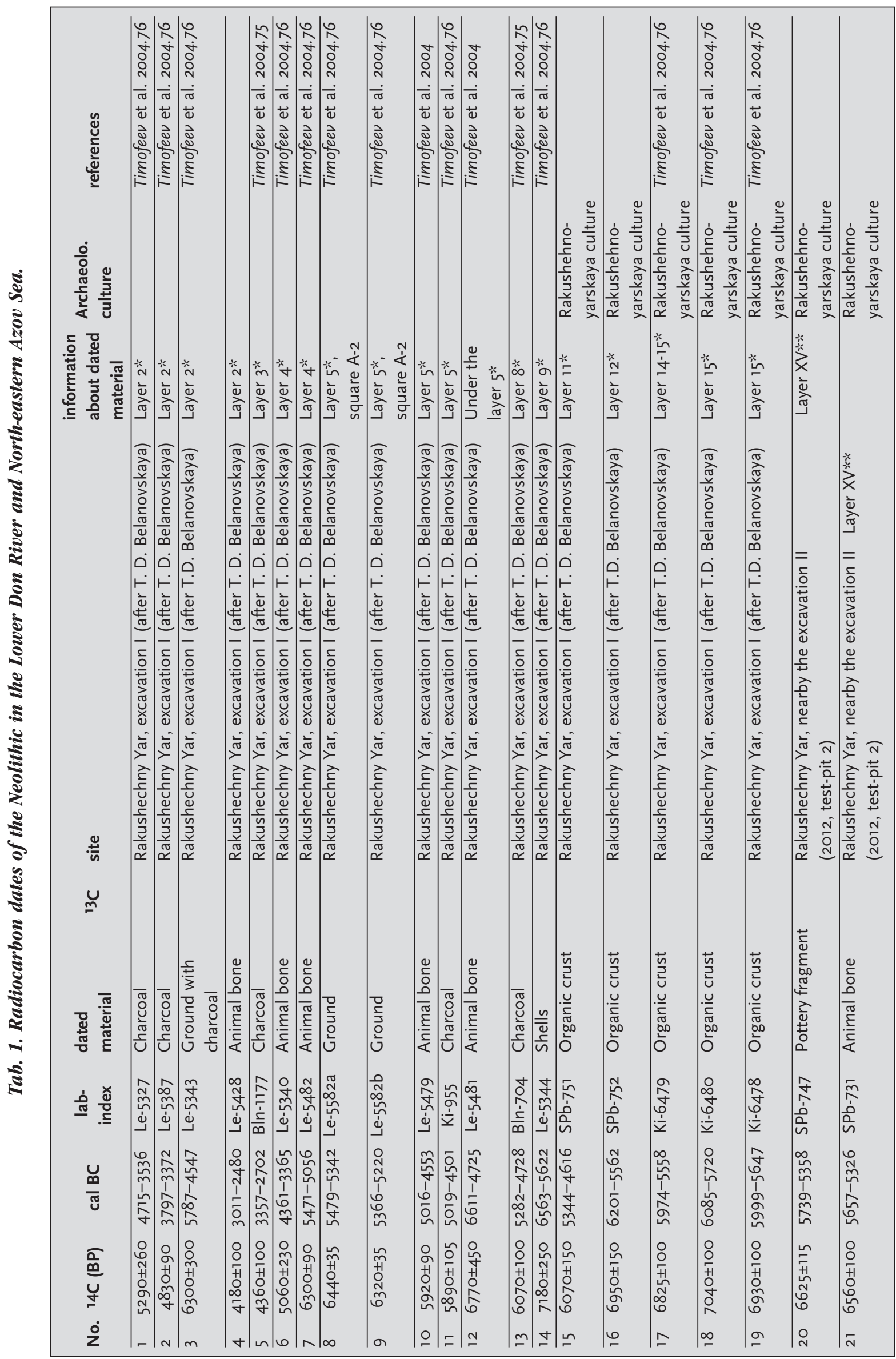




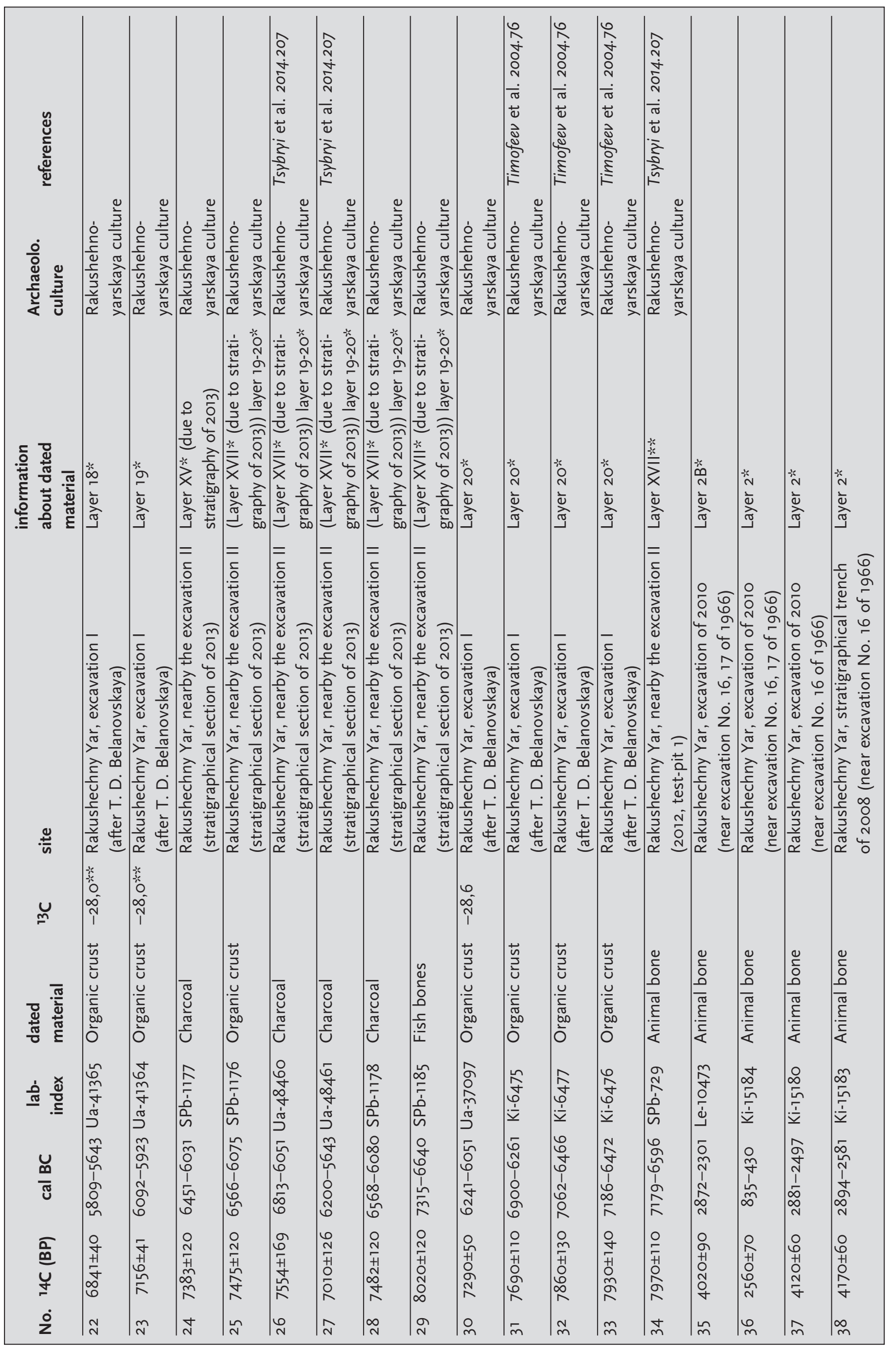




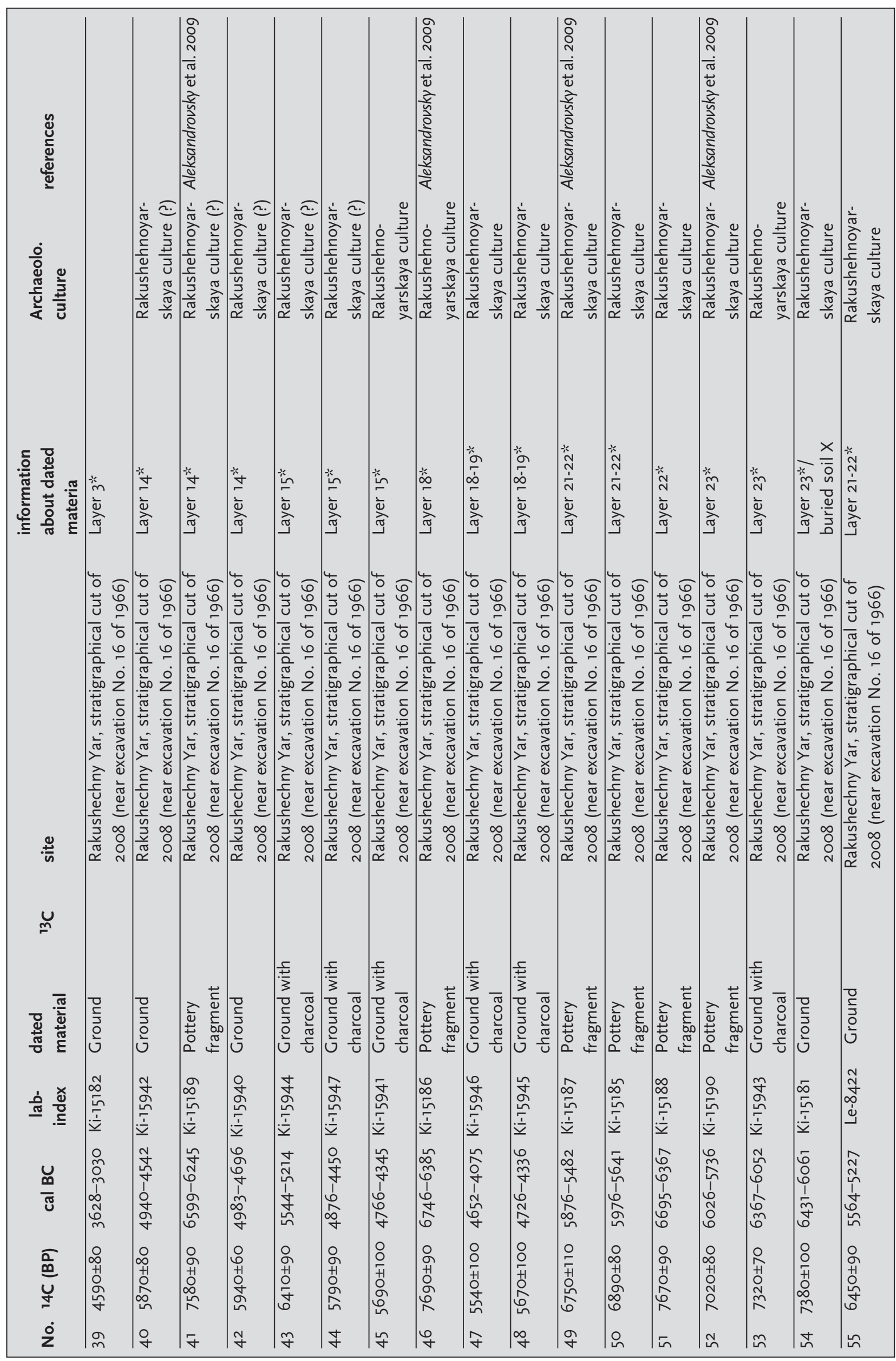




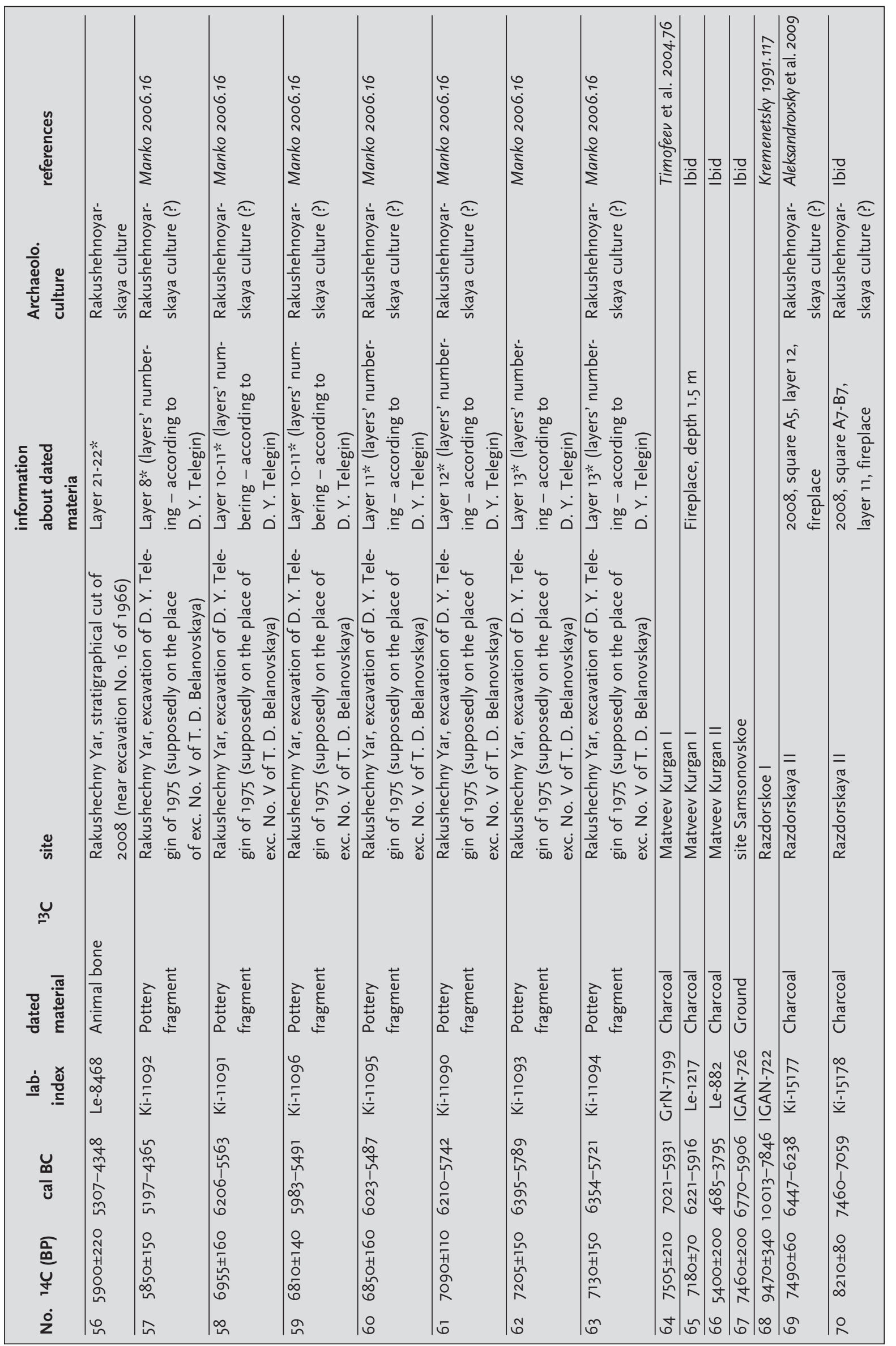




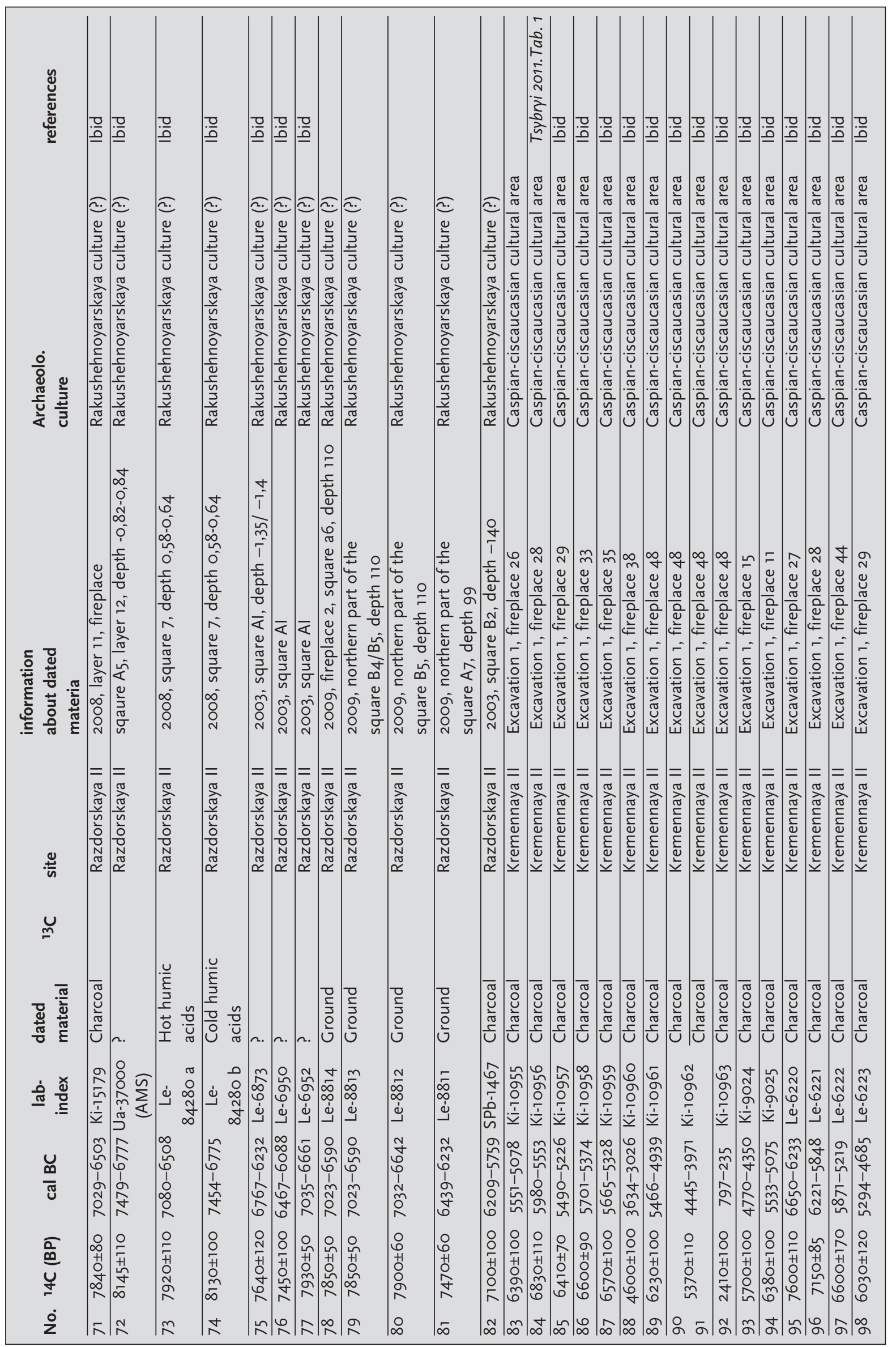




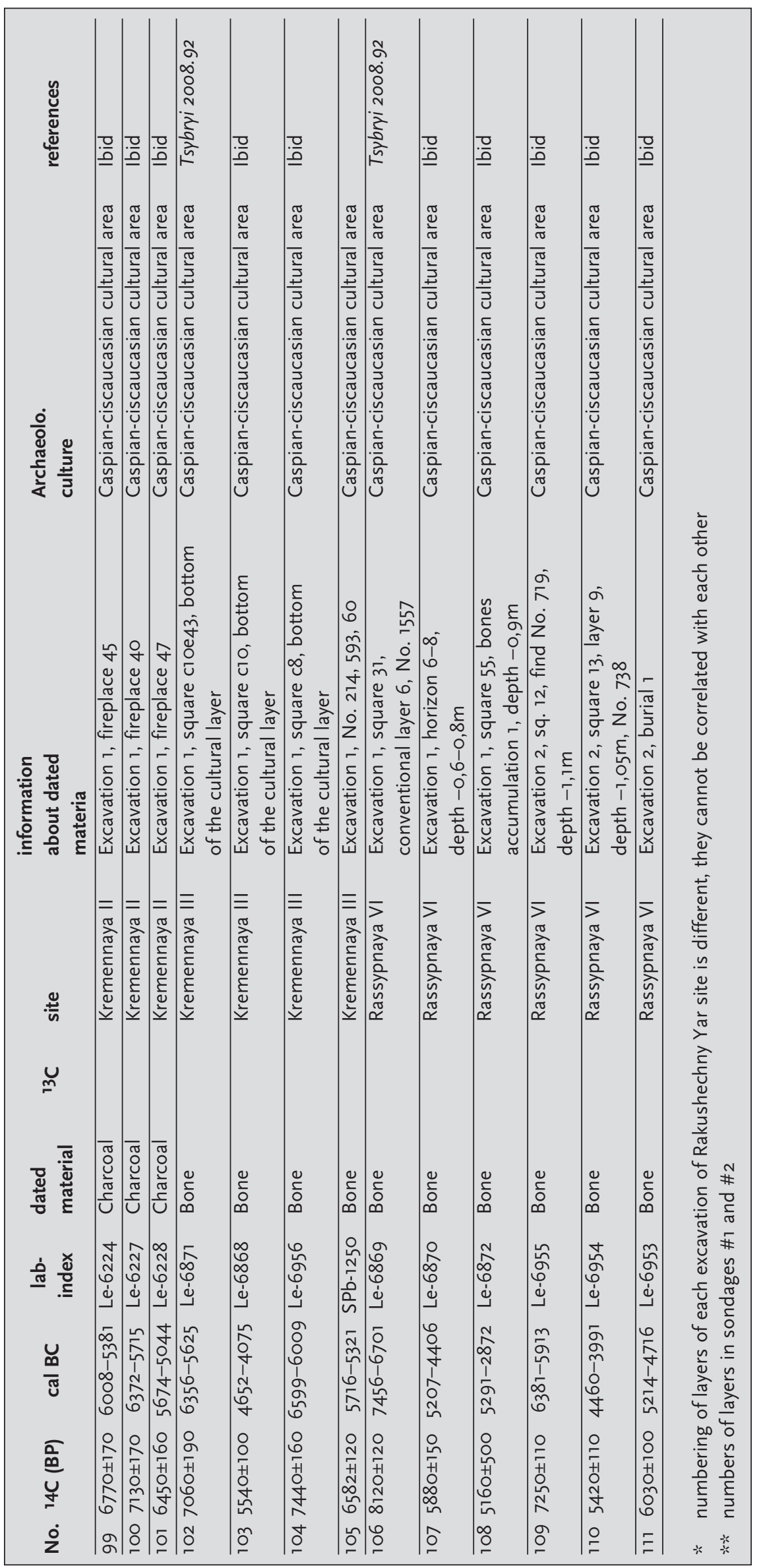

